\title{
norden
}

\section{Sustainability certification of Nordic tourist destinations}

Report from an expert workshop in Stockholm 11th September 2012

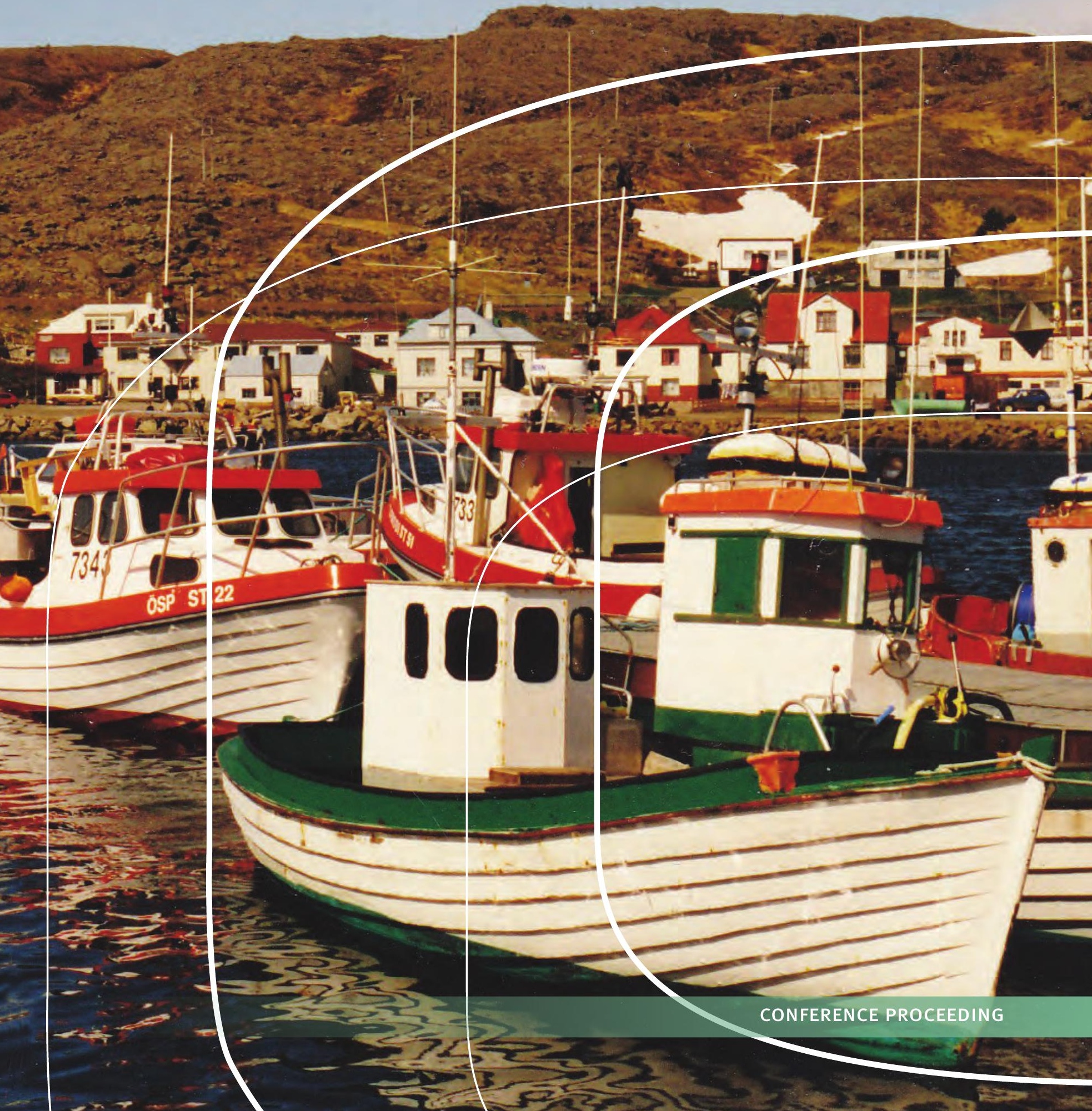



4 norden 



\section{Sustainability certification of Nordic tourist destinations}

Report from an expert workshop in Stockholm $11^{\text {th }}$ September 2012

Stefán Gíslason 
Sustainability certification of Nordic tourist destinations

Report from an expert workshop in Stockholm 11 ${ }^{\text {th }}$ September 2012

Stefán Gíslason

ISBN 978-92-893-2545-5

http://dx.doi.org/10.6027/TN2013-530

TemaNord 2013:530

(C) Nordic Council of Ministers 2013

Layout: Nordisk Ministerråd

Cover photo: Stefán Gíslason

This publication has been published with financial support by the Nordic Council of Ministers. However, the contents of this publication do not necessarily reflect the views, policies or recommendations of the Nordic Council of Ministers.

\section{www.norden.org/en/publications}

\section{Nordic co-operation}

Nordic co-operation is one of the world's most extensive forms of regional collaboration, involving Denmark, Finland, Iceland, Norway, Sweden, and the Faroe Islands, Greenland, and Åland.

Nordic co-operation has firm traditions in politics, the economy, and culture. It plays an important role in European and international collaboration, and aims at creating a strong Nordic community in a strong Europe.

Nordic co-operation seeks to safeguard Nordic and regional interests and principles in the global community. Common Nordic values help the region solidify its position as one of the world's most innovative and competitive.

\section{Nordic Council of Ministers}

Ved Stranden 18

DK-1061 Copenhagen $\mathrm{K}$

Phone (+45) 33960200

www.norden.org 


\section{Content}

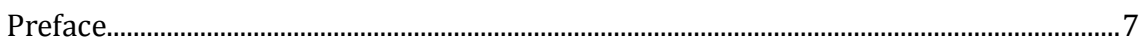

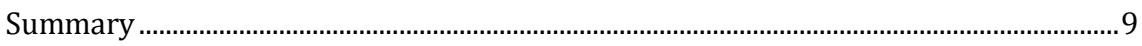

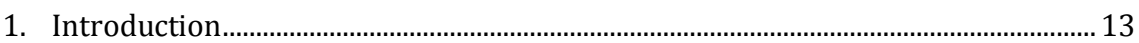

1.1 Workshop background ................................................................................... 13

1.2 Report outline....................................................................................................... 14

2. Workshop in Stockholm 11 September 2012 ........................................................... 15

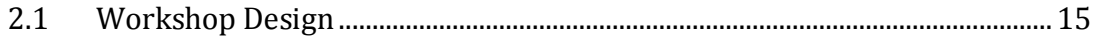

2.2 Participants................................................................................................ 15

2.3 Presentations ...................................................................................................... 16

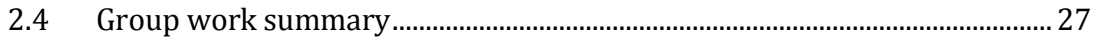

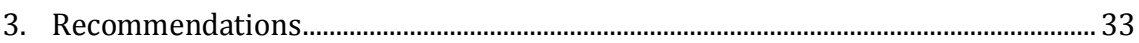

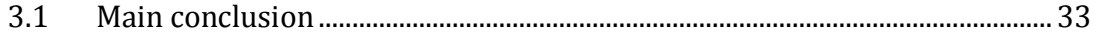

3.2 Destinations defined....................................................................................... 33

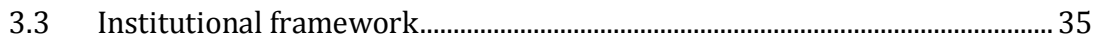

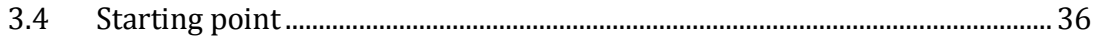

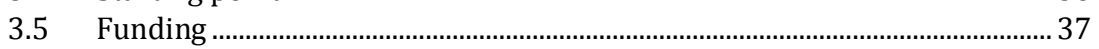

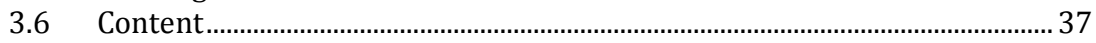

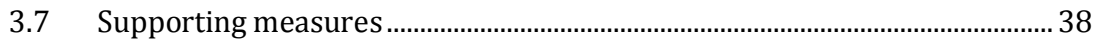

3.8 Important considerations.............................................................................. 39

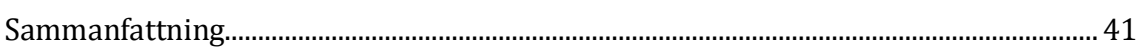

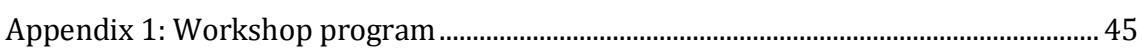

Appendix 2: Workshop participants ............................................................................. 47 



\section{Preface}

An expert workshop on sustainability certification of tourist destinations was held at The Swedish EPA (Naturvårdsverket) in Stockholm Tuesday the $11^{\text {th }}$ of September 2012. The objective of the workshop was to create a professional and reliable foundation for decision and policy making within the Nordic Council of Ministers and the individual Nordic countries regarding sustainability certification of tourist destinations, building upon a study conducted in 2011 by Environice for the Nordic Council of Ministers. This report contains a summary of the workshop discussions and the main conclusions and recommendations derived from them.

The workshop was organized by Environice consulting in Iceland on behalf of the Nordic Council of Ministers' Group on Small Communities (Småsamfundsgruppen), which is a subgroup of the Council's Working Group on Sustainable Consumption and Production (HKP-gruppen).

Several experts contributed to the workshop as well as to the compilation of the main results and recommendations. These people deserve a lot of gratitude, including special thanks to the invited speakers, to the workshop participants and to the members of the Nordic Group on Small Communities.

The main conclusion of the workshop was that the Nordic countries should develop a common Nordic system for sustainability certification of tourist destinations. It is our hope that this workshop report will serve as a useful starting point for this work.

January 2013

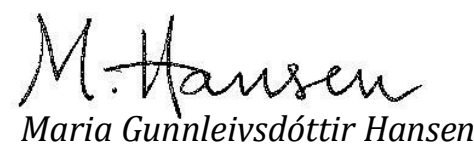

Chair of the Nordic Group on Small Communities, Umhvørvisstovan Tórshavn

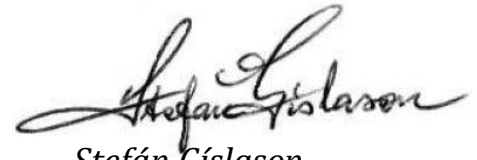

Stefán Gíslason

Project leader

Environice

Borgarnes 



\section{Summary}

An expert workshop on sustainability certification of tourist destinations was held at the Swedish EPA (Naturvårdsverket) in Stockholm Tuesday the 11 th of September 2012. The objective of the workshop was to create a professional and reliable foundation for decision and policy making within the Nordic Council of Ministers and the individual Nordic countries regarding sustainability certification of tourist destinations.

Globally, the number of sustainability certification systems for tourism destinations is relatively small. A study, conducted in 2011 by Environice (Stefán Gíslason and Venus Krantz) for the Nordic Council of Ministers, identified only four existing systems concerning environmental or sustainability certification for tourist destinations. One of the recommendations from the study was that the Nordic countries should develop their own certification system for this purpose.

The workshop in Stockholm aimed to build on the Environice study and to explore and widen its recommendations by involving more stakeholders with different views, and by sharing knowledge and experiences from relevant projects and pilot-cases. The workshop was commissioned by the Nordic Council of Ministers' group on small communities (Småsamfundsgruppen).

The workshop was carried out in one day. The first half was dedicated to introductory presentations of different projects and pilot-cases. During the second half the findings from the presentations and the report from the Environice study were discussed in parallel in three groups, seeking an answer to the question of whether the Nordic countries, individually or within the Nordic Council of Ministers, should create their own system for sustainability certification of tourist destinations, or whether they should contribute to such a system created by someone else, or whether national Nordic initiatives should be developed into a Nordic system or whether the Nordic countries should await the development within the EU and on the international level.

The 16 participants in the workshop were chosen based on their professional experience and involvement in sustainable tourism on the destination level or in particular in sustainability certification of tourist destinations. Formally, the workshop was open to everyone interested in the topic and willing to contribute to the discussion. However, this 
was mainly supposed to be an expert workshop with a limited number of participants.

The main conclusion of the workshop was that the Nordic countries should develop a common Nordic system for sustainability certification of tourist destinations. The need exists according to the Environice report and existing and upcoming systems do not seem to meet this need. This situation provides an opportunity for the Nordic countries that are known for being "green" and for having a political interest in sustainable development. A properly developed system for sustainability certification of tourist destinations could give them a first-mover advantage.

Involved actors need to have a common understanding of the destination concept. As pointed out in an array of tourist studies, there is still confusion as to what the destination concept actually means, even though this concept is very much in focus in such studies. Existing studies, the results from the Environice study and several comments from the workshop participants can be summarized into the following five criteria, which would all have to be met in order for a tourist destination to be eligible for sustainability certification as proposed in this paper:

- A geographic place or area with certain physical boundaries where people live in an organized fashion for a long time and which bears visible and permanent traces of social formation in the form of houses and other buildings where people live and spend time.

- A community where people share a common economic, social and industrial infrastructure, common institutions and, to a greater or lesser extent, a common culture.

- A community that is wholly or partially dependent on tourism for its survival.

- An administrative unit with certain administrative boundaries and a properly constituted community authority or a destination management organization (DMO), such as a local government, with its own budget and power to make decisions regarding the management of the destination.

- In most cases a locality, a town, a municipality or a group of municipalities below regional level (sub-regional).

The Nordic certification system for destinations needs to have a vivid and stable institutional base. A decision on the institutional framework needs to be made during the initial stage of development, preferably within the Nordic Council of Ministers, i.e. by the Nordic Council of Ministers for the Environment (MR-M), on one hand, and the Nordic Council 
of Ministers for Business, Energy \& Regional Policy (MR-NER), on the other. The Nordic Swan should be seen as a role model with regard to the framework.

A Nordic system for sustainability certification of tourist destinations should build on the core indicators developed by the EU Commission's TSG (Tourism and Sustainability Group) in 2009, as well as on the GSTC criteria for the destination level, which will be available before the end of 2012. ISEAL's credibility principles should also be taken into account.

At the same time that the Nordic system has to be comparable and be on a high international level of quality and sustainability, it also needs to be on an appropriate level from a Nordic perspective. This means that the system will be somewhat different from a system designed for the EU as a whole, in being more specific and with stricter requirements on a number of issues. The criteria of the system should be achievable by a maximum of $30 \%$ of Nordic destinations.

More than 20 years of experience and vast knowledge has been collected during the Nordic cooperation around the Swan ecolabel. The Nordic Swan should play an important advisory role during the development phase of a Nordic system for sustainability certification of tourism destinations, even though it may not fit in as a part of the Swan system as such. It would also be advantageous to build upon the experience and knowledge acquired during the development of Destination 21 in Denmark.

The certification system being developed by Innovation Norway could be used as a basic platform for the Nordic system. It is highly recommended that Innovation Norway is involved in the development of the system from near the beginning.

Funding of the new system should be included in any planning of the system from the beginning. It is essential to make it as clear as possible from the start how the system can be maintained over a longer period of time. Government funding will be needed in the development phase and to some extent later on.

A few factors are essential as parts of the system. First of all, the sustainability of the whole destination should be in focus. It is also essential to take all three pillars of sustainable development into account. The system needs, in other words, to focus on social, cultural and economic issues, as well as the environmental ones.

Public participation should be highly prioritised and processes for innovation, on-going learning, awareness raising, training and knowledge sharing within and between destinations should be a part of the system from the early development on. 
The system should be a single state system where destinations either "pass or fail." Recertification should be required at least every third year and the destinations should be required to hand in annual reports with reliable performance data. External auditors should be employed.

The system should have a built-in flexibility to reflect the local context, as destinations may vary considerably between the Nordic countries and even within each country, such as because of different population density, location, cultures, etc. Small and remote communities do, for instance, often face different challenges from a sustainability point of view than more densely populated or more centrally located areas. The standard needs to include mandatory and optional criteria for processes and performances, complemented with measurable indicators.

The system has to be made as user-friendly as possible, especially during the initial stages. Any unnecessary bureaucracy would undermine the system and hamper its success.

A certification system as proposed in this report is likely to create a fruitful soil for new products and a common understanding of where the Nordic countries are heading. At the same time it would bring new opportunities for the marketing of the Nordic countries, which the visitor often perceives as a whole.

Even though the certification will always be the central part and the main objective of the system, it should be kept in mind that the longterm effect of the certification process as such may actually be the most valuable part of all. 


\section{Introduction}

\subsection{Workshop background}

An expert workshop on sustainability certification of tourist destinations was held at the Swedish EPA (Naturvårdsverket) in Stockholm, Tuesday the $11^{\text {th }}$ of September 2012. The objective of the workshop was to create a professional and reliable foundation for decision and policy making within the Nordic Council of Ministers and the individual Nordic countries regarding sustainability certification of tourist destinations.

Globally, there are many different initiatives for measuring and communicating sustainable development within the tourism industry. In a 2001 study the World Tourism Organization (UNWTO) found more than 260 different voluntary initiatives for the sustainable tourism industry, such as benchmarking, manuals of best practices, awards, codes of ethics, environmental labelling and certification. A large number of these focus on environmental or sustainability certification of individual companies, products or services. The number of sustainability certification systems for tourism destinations is, however, relatively small. A study, conducted in 2011 by Environice (Stefán Gíslason and Venus Krantz) for the Nordic Council of Ministers' group on small communities (Småsamfundsgruppen), identified only four existing systems concerning environmental or sustainability certification for tourist destinations. ${ }^{1}$

One of the recommendations from the Environice study is that the Nordic countries should develop their own system for sustainability certification of tourist destinations. There is a need for this according to the study, and the existing systems can hardly be seen to be fulfilling this need. The basic blocks for a Nordic system are already available in the form of core indicators developed by the EU-Commission's TSG (Tourism and Sustainability Group), as well as in the upcoming GSTC's destination criteria to be published by the end of 2012. The study also pointed out that a new initiative coordinated by the Norwegian Innovation

${ }^{1}$ Stefán Gíslason and Venus Krantz (2012): Hållbarhetscertifiering av turistdestinationer. Utredning av möjligheter i en nordisk kontext: Befintliga standarder eller ett nytt nordiskt system? TemaNord 2012:531. Nordic Council of Ministers, Copenhagen. http://www.norden.org/sv/publikationer/publikationer/2012-531 
Centre would be worth following during its test period of 2012. This could possibly be developed in one way or another to cover the entire Nordic region.

The workshop in Stockholm aimed to build on the Environice study and to explore and widen its recommendations by involving more stakeholders with different views, and by sharing knowledge and experiences from relevant projects and pilot-cases. The outcome of the workshop was expected to include a timed action plan with well-defined measures to be taken by the Nordic Council of Ministers.

The workshop was commissioned by the Nordic Council of Ministers' group on small communities (Småsamfundsgruppen).

\subsection{Report outline}

This report includes a summary of the workshop's group discussions, followed by a structured proposal for future work, based on the workshop results.

Chapter 2 describes the design of the workshop and the choice of participants. The main content of the chapter consists of a short summary from all the presentations given at the workshop.

Chapter 3 presents policy recommendations for the Nordic countries and for the Nordic Council of Ministers, based on the recommendations from the Environice study, with contributions from the workshop participants.

The report is supplemented with appendices, with the workshop programme, a list of participants and copies of all the presentations. 


\section{Workshop in Stockholm 11 September 2012}

\subsection{Workshop Design}

The workshop was carried out in one day from 10 am to $4 \mathrm{pm}$, (see workshop programme in Appendix 1). The first half was dedicated to introductory presentations of different projects and pilot-cases. During the second half the findings from the presentations and the report from the Environice study were discussed in parallel, in three groups.

The groupwork was divided into two halves. During the first half, the members of each group discussed and listed the 4 points from the Environice study and/or the presentations that they found most interesting and tried to rank them in order of priority.

During the second half, the group members sought an answer to this question: "Should the Nordic countries, individually or within the Nordic Council of Ministers, create their own system for sustainability certification of tourist destinations, should they contribute to such a system created by someone else, should national Nordic initiatives be developed into a Nordic system or should the Nordic countries await the development within the EU and on the international level?"

Each group chose a rapporteur who documented the main results of the discussion and presented them in a short plenary session at the end of the day. These results are to be seen as the main outcome of the workshop.

\subsection{Participants}

The participants in the workshop were chosen based on their professional experience and involvement in sustainable tourism on the destination level or in particular in sustainability certification of tourist destinations. Formally, the workshop was open to everyone interested in the topic and willing to contribute to the discussion. However, this was mainly supposed to be an expert workshop with a limited number of participants (approximately 20 persons). A list of workshop participants is to be found in Appendix 2 . 
The report from the Environice study was sent out to the workshop participants prior to the workshop to make it possible for them to acquaint themselves with the content, especially the results and recommendations. A short version of the recommendations was also included in the workshop proceedings.

Figure 1. A few of the workshop participants: Herbert Hamele, Ingunn Sørnes, Nanna Balsby, Evelina Persson, Björn-Erik Lönn, Louise Rabilloud, Venus Krantz and Theódóra Matthíasdóttir.

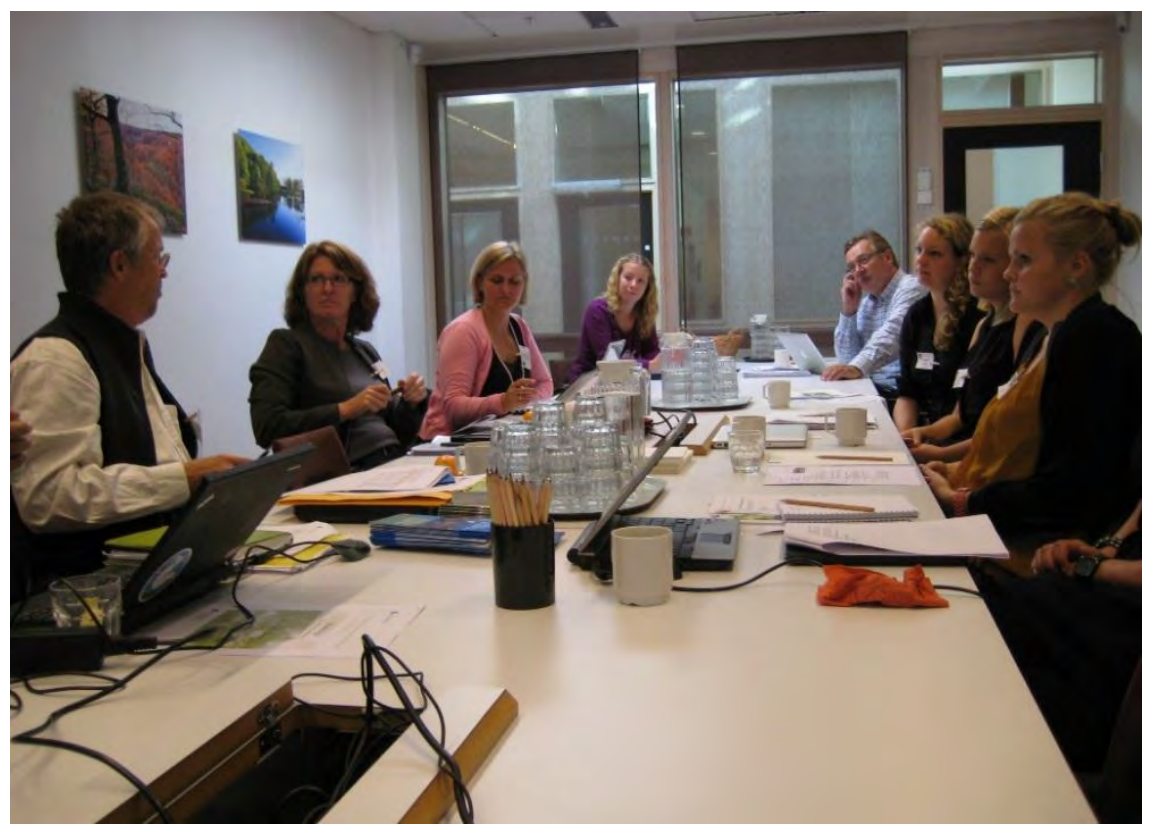

Photo: Stefán Gíslason.

\subsection{Presentations}

This section includes a short summary from the presentations given at the workshop. Copies of all the presentations are available in Appendix 3.

\subsubsection{Venus Krantz and Stefán Gíslason}

Venus and Stefán presented the main findings of the report "Hållbarhetscertifiering av turistdestinationer. Utredning av möjligheter $i$ en nordisk context: Befintliga standarder eller ett nytt nordiskt system?" which they compiled for the Nordic Council of Ministers' group on small communities (Småsamfundsgruppen), i.e. the report to be followed up 
by the workshop. Their study, which was mainly carried out in spring 2011, had the objective of creating a sound basis for the Nordic authorities for decisions regarding possible environmental or sustainability certification of tourist destinations. To build this basis, answers were sought to the following three questions:

- How is the current situation and the availability of sustainability certifications for tourist destinations?

- What are the strengths and weaknesses of the current systems?

- What are the opportunities and obstacles for sustainability certification of Nordic tourist destinations?

In their study, Venus and Stefán identified only 10 systems for certification or for monitoring sustainability with relevance for tourist destinations, while a couple of hundreds such systems were available for individual tourism companies. From these 10 systems only 6 could be defined as certification systems. Two of these were not included in the study because of lack of information or lack of relevance to the tourism industry. The four remaining systems; EarthCheck, Destination 21, STEP and SCP (Audubon) were explored in more detail. As a result of this exploration only EarthCheck and Destination 21 were perceived as sufficiently accessible and/or relevant for further examination/comparison. EarthCheck is an Australian based global system for certification of tourist destinations (communities), with a total of 4-5 certificates issued, while Destination 21 is a Danish system, thoroughly developed and documented more than 10 years ago, yet without any successful implementation.

It has to be mentioned in this context that the comparative part of the study in question was concluded before the launch of Innovation Norway's project on Sustainable Tourism 2015 (see the presentation of Ingunn Sørnæs).

For the next part of the study, the criteria of EarthCheck and Destination 21 were compared to each other and to the set of indicators for sustainable development on the destination level that EU's Tourism Sustainability Group (TSG) developed and tested in 2010. Comparison could also have been done with the new Global Sustainable Tourism Council (GSTC) Draft Criteria for Destinations, but these had not been published at the time of the study.

The comparison with the TSG set of indicators showed that most of these were to be found in both systems, i.e. both in EarthCheck and in Destination 21, yet in different ways. 
Case-study of the Snæfellsnes peninsula in Iceland was done as a part of the study being discussed, but Snæfellsnes is the only destination in Europe that has achieved EarthCheck certification. The experience from Snæfellsnes is explained in another presentation at the workshop.

A simple need analysis was carried out as a part of the study, based on an internet-based questionnaire sent out to representatives from the tourism and municipal sectors in Iceland, Faroe Islands, Åland, Greenland and Norway. A total of 94 replies were received, building a useful basis for general conclusions, without giving rise to any major statistical analysis. Some $40-80 \%$ of the respondents (different between countries) said that there is a strong or a very strong need for sustainability certification of tourist destinations. National actors were most frequently mentioned when respondents were asked who should take the initiative. The replies, however, pointed to the idea that the system should be coordinated for a larger area. An improved framework for the destinations' sustainability efforts was among the opportunities that would lie in such a system, according to the respondents; the system should be state funded to begin with, but it should never become too dependent on revenues for future survival.

The main conclusions of the Environice report were summarised in the following set of recommendations (a short version):

- The Nordic countries should develop their own system for sustainability certification of tourist destinations. The need exists according to the results of the project and it is perceived as hard to see how EarthCheck can meet this need. Other systems do not seem to be on their way.

- A new initiative coordinated by the Norwegian Innovation Centre is worth following during its test period of 2012. This could possibly be developed in one way or another to cover the entire Nordic region. The cornerstones for such a Nordic system are to be found in core indicators developed by the EU Commission's TSG (Tourism and Sustainability Group) in 2009, as well as in the GSTC criteria for the destination level, which will be available before the end of 2012 .

- More than 20 years of experience and vast knowledge has been collected during the Nordic cooperation around the Swan ecolabel. This is an obvious source for the development of a Nordic system for sustainability certification of tourism destinations, whether it will be built in cooperation with the Nordic Swan or as part of the Swan's development. 
- Funding of a new system should be included in any plan from the beginning, to make it as clear as possible how the system can be maintained. Government funding will be needed in the development phase and to some extent over a longer period.

- The system should include criteria and measurable indicators for social and economic aspects in addition to the environmental ones. Furthermore, public participation should be in focus while developing the system, ensuring inclusion and motivation at the destination level.

- The certification should be both process- and performance-based and cover the entire destination as far as possible, but not just municipal operations. Furthermore, one should focus on a single state system where destinations either "pass or fail". A rating system is not recommended. Accessibility and transparency should be a priority.

\subsubsection{Herbert Hamele}

In his presentation Herbert Hamele discussed the trends and future for sustainable destinations and their certification. To begin with he introduced ECOTRANS, the European Network for Sustainable Tourism Development that was founded in 1993. Then he introduced UNWTO's and UNEP's 12 aims for an agenda for sustainable tourism, which are relevant to all destinations. He underlined the importance of stakeholder involvement in making tourism more sustainable and in the certification process as such. Destinations are central to marketing efforts to promote relevant offers and brand messages.

In his presentation Herbert identified some main tendencies in the certification work. The main characteristic of these is an increased focus on multidimensional issues, such as on the certification of destinations and a more global approach. The main tendencies, according to Herbert, are as follows:

- Territory of operation:

Local $>$ regional $>$ national $>$ multi-national $>$ Europe $>$ global .

- Service groups:

Hotels $>$ accommodation \& restaurants $>$ attractions $>$ activities, transport, packages $>$ destinations.

- Environmental $>\&$ social, cultural, economic sustainability.

- Management $>$ performance $>$ processes \& performance.

- Minimize negative impacts $>+$ optimize benefits.

- Savings > + marketing. 
- Interest of businesses > + guests + population.

- Tourism $>$ destination as a whole.

- Collaboration $>$ competition.

- Single tool > integration with complementary tools \& initiatives.

European actors have already been operating environmental and sustainability certification systems for 25 years. This experience is most valuable when building up a system for destinations. EUROPARC has the most extensive experience regarding protected areas, the Austrian Ecolabel has begun to certify packages and Tourcert has given their CSRcertification to 58 tour operators. Many of the criteria of these systems are quite relevant for destinations, such as criteria on local/regional revenues. Ideas and opportunities for partnership could also be found in relation to the Scandinavian Sustainable Meetings Accord. Furthermore, destination management has been on the agenda of EMAS.

Several complementary initiatives towards sustainable destinations were mentioned, such as self-commitment and common branding of a group of towns; such as within the project "Alpine Pearls". The EDEN destination award is another example of a step towards more sustainable destinations. The DestiNet online platform has been developed to support destination development. A few more initiatives were mentioned, such as the Fast-Lain project and the initiative of the La Palma islands of the Canaries, where a group of stakeholders from businesses and municipalities have jointly set up the La Palma Club as a selfcommitted platform for knowledge networking and innovation. They are using DestiNet for local to global knowledge exchange and market access. DestiNet could, in a similar way, be used to support destinations in the Nordic countries, for instance through own restricted sections creating a platform for the development, operations and monitoring of a certification programme for the destinations.

According to Herbert, the Nordic countries could have a destination certification system of their own, but that system would have to be comparable and be on a high international level of quality and sustainability. The criteria should be selected from available European and global sources and complemented by tailor-made indicators. The sustainability of the whole destination should be in focus. A destination should in this context be defined below regional level (sub-regional). Social, cultural and economic aspects should be integrated into the set of criteria and processes for knowledge sharing and innovation within and between destinations should be a part of the system. The system should be a single state "pass or fail" system, with mandatory and optional criteria for processes and 
performances, achievable by $\geq 10 \%$ of the destinations. The optional criteria are likely to foster the diversity of destinations, which is quite an important issue from a sustainability point of view and also one of the reasons why a global system is not necessarily a good option.

\subsubsection{Mikael Backman}

Mikael Backman, from the International Institute for Industrial Environmental Economics (IIIEE) at Lund University contributed to the workshop with some reflections from practice. He pointed out that today's travel and tourism is in fact the largest migration in mankind ever, happening every year. Mass tourism and eco-tourism cannot be seen as total opposites. Mass tourism really "consumes" tourist places, but since the impacts are concentrated they can be managed more easily. Ecotourism is more diverse and can be managed because of the small numbers. However, eco-tourism can also affect sensitive natural or cultural values and pave the way for mass tourism. Initiatives to promote sustainability should focus on both. Even mass tourism must adopt sustainable tourism principles. At its best tourism can contribute to the protection of nature and cultural heritage and even to peace on Earth, while at its worst it leads to widespread degradation and eventually kills itself.

The travelling patterns of tourists are changing and the "new tourist" is emerging. "The new tourist" has a demand for cleanliness, high quality, uniqueness, local identity, memorable experiences and, somewhat challengingly, few other tourists! "The new tourist" wants value for time and value for money!

Mikael recalled the so-called "Torremolinos-effect", where the destination declines for several reasons. The whole industry is in such cases developed around the tourist, not around the local population. The tourism demand and infrastructure investment also grows faster than the local industries' capacity to supply, the destination management is poor and targets, measureable indicators and communication are missing.

The trends of destinations are clearly towards better access, diversification of products and services, development of experience and knowledge, public-private partnerships and increased environmental awareness, to mention a few main issues. All-inclusive tourism is on the rise. All this motivates the tourism industry to look for innovation and differentiation in close co-operation with local communities.

Mikael also mentioned ideas being discussed in Skåne in Southern Sweden to make Skåne the most sustainable destination in the whole country. 


\subsubsection{Theódóra Matthíasdóttir}

Theódóra presented experiences from the co-operation of five local authorities in the Snæfellsnes peninsula in Iceland, who joined forces soon after the turn of the century to have the whole region certified as a sustainable tourist destination.

The Snæfellsnes region is a sparsely populated peninsula in western Iceland, with a total of 4,000 inhabitants in 5 municipalities. The majority of the population lives in three fishing villages, with some 1,000 inhabitants each. The idea to have the region certified had roots in the Local Agenda 21 (LA21) work in one of the municipalities, originally because of a perceived lack of external supervision in the flexible and voluntary LA21 approach. Two pioneers within the tourism industry were invited to a conference in 2002, where the idea of certification was introduced for the first time. At this point in time, Green Globe was already in the process of developing a community standard, applicable to tourist destinations. In 2003 the five local authorities formally created a coalition to work on this goal. Green Globe was a natural partner, being the first organization to offer certification for a community or a destination as a whole. The national government provided funding for this work, as it was seen as a pilot project, paving the way for other regions to follow.

The Snæfellsnes region reached Green Globe benchmarking status in 2004, which means that they passed a comparison of their sustainability performance against certain baseline criteria set out by EarthCheck, in co-operation with Green Globe. Full certification was achieved in 2008, having failed at the first attempt in 2006. Since then, certification has been renewed annually or every second year, most recently in 2011. During this period EarthCheck took over the programme and the EarthCheck logo replaced the Green Globe logo of certification.

According to Theódóra the Snæfellsnes region has accomplished a lot in relation to the implementation of the system. The following achievements were mentioned, among others:

- A monitoring system is now in place for several performance indicators that are part of the EarthCheck benchmarking system.

- An environmental management handbook has been developed for the region as a whole with relevance to each of the five municipalities.

- A new purchasing policy has been adopted with preferences given to ecolabelled products.

- Waste management has been substantially improved. 
- Every kindergarten and elementary school participates in the Green Flag project.

- Two harbours have received the Blue Flag.

- A project has been initiated to fight invasive species.

- The town of Stykkishólmur got the EDEN award in 2011.

Some problems have arisen as well, as can be expected in a pilot project like this. The region started its work while the Green Globe standard for communities, and the certification system as a whole, were still in the early phases of development. This caused considerable inconvenience and extra costs. Some difficulties have also been experienced in relation to data collection etc., mainly due to lacking documentation and traceability within local, regional and national institutions and companies.

The fact that EarthCheck has its headquarters in Australia has also made the work a bit more difficult. Time differences contribute to this, but the main problem is that the standard is often hard to apply to Icelandic conditions. The system is neither very well known in Iceland nor in other parts of Europe.

As mentioned above five municipalities in the Snæfellsnes region are co-operating on the project. The local governments do have somewhat different ways of thinking and the coalition they created does not have a strong constitutional status. There is also a tendency to rely too much on the project co-ordinator, even though the whole concept cannot really be taken further without serious commitment by all partners, especially the local governments. Lack of money has also turned out to be a problem, even though considerable state funding has been provided until recently.

At the end of her presentation Theódóra expressed her dreams for the future of the project. The following items were on top of that list:

- Increased number of certified businesses in the area.

- More involvement of the local governments.

- More involvement of the inhabitants.

- Better marketing opportunities.

- Increased focus on economic and social aspects.

- Nordic or European label.

\subsubsection{Ingunn Sørnæs}

Ingunn Sørnæs works as a project leader for the programme Sustainable Tourism 2015 at the Norwegian Innovation Centre. As a part of this, the centre has initiated a pilot project to develop a certification system for 
sustainable tourist destinations in Norway. This work is based on UNWTO's and the EU's definitions, and on GSTC criteria and indicators. The aim is to build a national process and to establish tools and instruments for industry, planning authorities, education, etc.

In her presentation Ingunn gave an overview of the Norwegian project. A high emphasis is put on involving stakeholder groups, increasing awareness, suggesting actions and providing training to prepare for environmental/sustainability certification. Four pilot destinations have been selected from a group of 30 applicants to develop the methodology and the set of criteria and to do the necessary real-time testing. These four are Røros, Vega, Trysil and Lærdal, representing different kinds of destinations in terms of nature, main activities, etc. As a part of the project, sustainability has to be integrated into strategies and plans, marketing, funding, analysis and training programmes, both at the national, regional and local levels.

The Norwegian work on sustainable destinations has been on-going since 2009. This has included an international search for models to follow. Then connection to GSTC was established. As mentioned above GSTC has developed a set of criteria for sustainable destinations, which is now being tested in a few pilot destinations worldwide. The region of Fjord Norge is one of these early adopters.

The development of the Norwegian certification system has a background in the national tourism strategy adopted in 2012. The work is supported by a reference group with representatives from different authorities and associations, as well as from the Nordic Swan and the EcoLighthouse Foundation, which operates the national Eco-Lighthouse certification scheme.

The Norwegian system is based on 46 criteria and 85 indicators to monitor their follow-up. The criteria and the indicators refer to all three pillars of sustainable development. A handful of them also focus on commitment in the destination and on political implementation of sustainable practices. The first stages of the process require local or regional funding, while the last steps, such as the audit and certification, are meant to be financed nationally. Recertification is required every third year, but annual reports have to be handed in. The aim is to create a national brand with an international recognition through GSTC approval/accreditation.

Version 2 of the criteria is currently under revision, which will be finished by November 2012. Tools and instruments are being developed, training of project leaders and advisors is already taking place, the financing structure is being discussed and the whole idea is being 
integrated into on-going restructuring of DMOs and tools for destination management.

Ingunn also mentioned that in order to make it easier for tourists to travel green, a database of all eco-certified providers of tourism services in Norway has been developed at www.visitnorway.com

The Norwegian Innovation Centre is interested in collaboration with all partners that share the ambition to work for more sustainable tourist destinations.

\subsubsection{Christina Rådelius}

Christina explained how the Swedish Agency for Economic and Regional Growth (Tillväxtverket) is working with tourism at the national level. The overall aim of the Agency is to work for innovation in companies and regions and to make it easier for companies to improve their performances.

Tillväxtverket has been working on sustainable tourism development for several years. The main initiative is Sustainable Tourism Development, which has been running since 2009 in cooperation with the Tourist Council of Western Sweden (Västsvenska Turistrådet). Four Swedish regions are right now involved in the project as pilot regions, with small companies improving their sustainability economically, environmentally and socially. The pilot phase is supposed to continue until 2014. A fully integrated quality and sustainability scheme for the tourism industry is being developed and will be formally launched in 2015 .

Participating companies are assessed annually by professional advisors and advice is given for improvements. The assessment is done through planned meetings every second year and by random visits by an unknown assessor during the other year. The report given to the company consists of 132 assessment items sorted into 18 groups of aspects. However, this is not meant to be a certification system as such. The main objectives are to help give the visitors confidence to choose Swedish experiences that meet or even exceed their expectations, to help companies to become even better, to support the development of export mature destinations and to guide the tourism industry towards sustainability. This system can be combined with other certification systems. More information can be found at www.hallbarbesoksnaring.se.

Tillväxtverket is also working on the project Sustainable Tourism Destinations, which will be carried out in the period 2012-2014. This is done in cooperation with VisitSweden and 5 selected destinations, i.e. Kiruna, Åre, the Stockholm Archipelago, Bohuslän and Vimmerby. A bottom-up approach has been important initially, even when it comes to 
sustainability. Three of these destinations already take part in the above mentioned initiative Sustainable Tourism Development and the other two are being offered it as a method of improving the quality of the products being offered by the companies at the destination. The two projects will, so to say, be intertwined at the local level.

\subsubsection{Björn-Erik Lönn}

Björn-Erik has worked for several years as the Nordic coordinator for the Nordic Swan. He presented the Swan at the workshop, went briefly through its history and explained the characteristics of Type 1 ecolabels, for which the Swan is a typical example.

Björn-Erik also presented the ISEAL Alliance, which is the global association for sustainability standards. ISEAL is working on credibility principles. Thirteen draft principles are now undergoing a public global consultation until June 2013.

The ultimate aim of sustainability standards systems is to bring about positive social, environmental and economic impacts, i.e.:

- Performance. Each part of the system must operate well.

- Uptake. The standard system must be used and trusted.

The thirteen draft principles are divided into these two groups. However, many of the principles contribute to both performance and uptake.

If a Nordic system is to be created for certification of destinations, it has to be made clear from the beginning for whom it is, i.e. who is the target group. The Nordic Swan could play an advisory role during the development phase. 


\subsection{Group work summary}

This section includes the main results from the groupwork during the workshop, compiled by the rapporteurs of each group.

\subsubsection{Group 1}

\section{Some of the points being discussed}

- Should Innovation Norway and the Nordic Swan be linked to build a system for certification of destinations?

- The Nordic Swan is not going to have criteria for tourist destinations. For whom is the certification? The Nordic Swan is established for Nordic consumers and purchasers.

- Controversial interests: Agriculture/tourism, how would this be affected by a certification of tourist destinations? Not willing to create extra bureaucracy, it costs money and it will work as long as there is EU/extra-funding, but otherwise not. It only works if continuous funding is available.

- Innovation Norway: The destination (not the municipality) is the owner of the certification. If it can be used in relation to marketing, it is interesting. Åland: It is important if Visit Åland can make use of it in marketing and if every company can be certified, which also would be rewarded as a part of the certification of the destination.

- When the system of Innovation Norway has been implemented, one will have created a summary and a sort of monitoring for the destinations.

This will create a positive atmosphere and when things can be measured people can show that they are doing better than the others.

- Big and small destinations are not facing the same challenges. Will one succeed in involving the municipality? The culture may be a destination as such in the larger ones. How to create a certification for a destination so diverse that it can be applied to all kinds of destinations?

- The municipality has the primary responsibility, which means that its role is crucial. The local authorities might not always be interested in certification even though other parts of the community are.

- How can a system be made to fit all kinds of destinations? 


\section{Four important points from the day (or actually only three)}

- Innovation Norway as a basic platform and something to learn from in the future.

- Snaefellsnes - resources and anchorage, an example of poor anchorage.

- Most important to involve and develop the tourism sector, not the public authorities, but the public authorities have the funds.

○ Link the certification to the tourism.

- A forum for the development of Nordic experiences, emphasize that what is sustainable tourism?

- Explain the Nordic differences, what is sustainability to them? Those who are running the projects within the Nordic countries should meet and discuss what is going on / what it is about / how it works.

- A perception of sustainability needs to be developed for the Nordic countries.

\section{How should a certification system for tourist destinations in the Nordic countries be created?}

National actors in the Nordic countries are not in the situation to create or adopt a system of their own. Such a system would "fit" best on that level, but not all are ready for that. It is not really clear which actors on the national level are in focus when talking about destinations. Who can say, for example in Sweden, that they are going to develop a system on the destination level? The municipality, the companies? It is better to co-operate.

Even though a Nordic system would be created, there is a risk that the EU comes in with its own system that would override the Nordic one. It has to be on the appropriate level, different from the level where the EU would come in, i.e. the EU system would be more general than the Nordic one.

\section{Members of the group}

- Ingunn Sørnes.

- Venus Krantz.

- Björn-Erik Lönn.

- Maria Gunnleivsdottir Hansen.

- Ulf Eklund.

- Rapporteur: Venus Krantz. 
Figure 2. Groupwork - Group 1: Maria Gunnleivsdottir Hansen, Ingunn Sørnes, Ulf Eklund, Björn-Erik Lönn and Venus Krantz

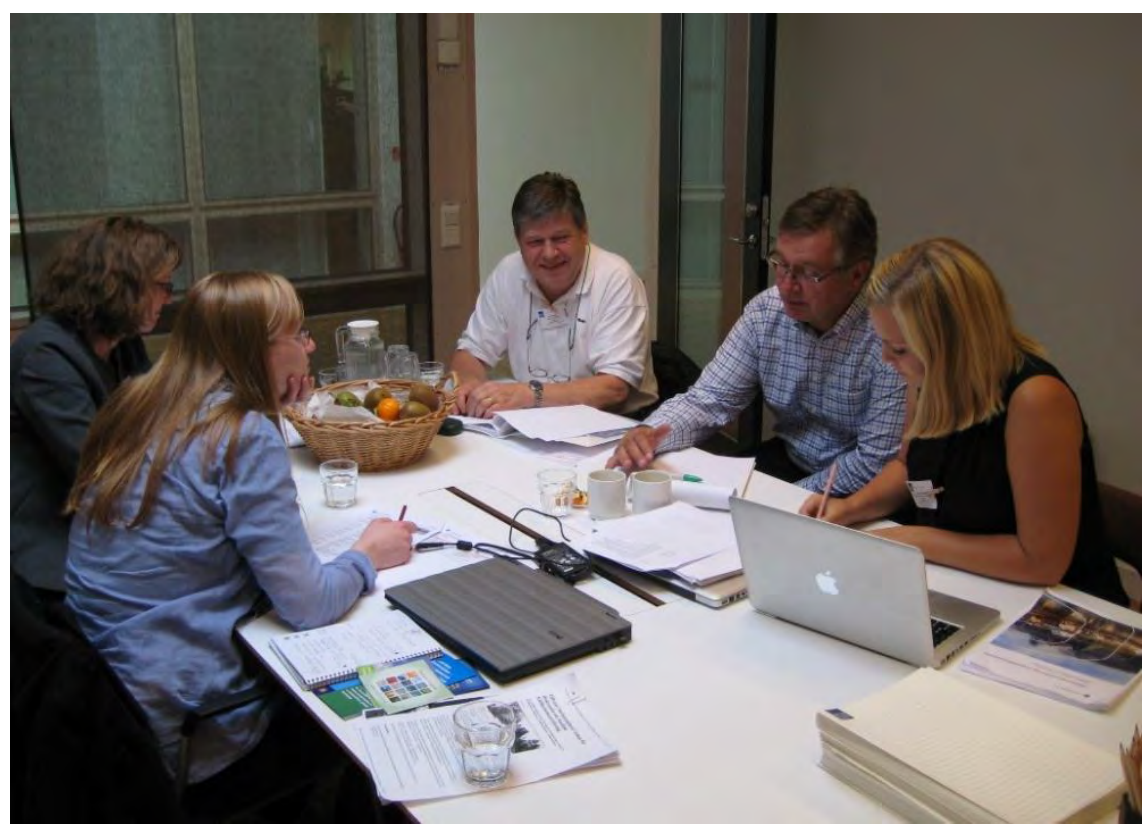

Photo: Stefán Gíslason.

\subsubsection{Group 2}

Important aspects to take into account in the developing of a certification system for destinations

- Sustainable development should be integrated into the whole community at the destination and should already be introduced in early childhood, i.e. it should be an integral part of the school curriculum.

- In the development of a certification system it should be made clear what is meant by "a destination" - i.e. clarification of concepts. It is for instance important, that there is an authority (e.g. the municipality) behind the development, to ensure that the DMO (Destination Management Organisation) has the power to make decisions.

- It can be extremely difficult to measure and provide data for the indicators, especially the economic and social ones.

- Long term financing must be thought of from the very beginning. 
- Environmental aspects should not be the only focus area, but also economic and social sustainability to a high extent. Some destinations face primarily environmental challenges, while others have more of the social ones.

- Branding and communication (both internally and externally) should be an important element to create the sense of ownership and authenticity. Branding should thus be an obligatory part of the criteria.

\section{There was a great support for developing a Nordic certification system}

- The Nordic countries are known for being "green" and for having a political interest in sustainable development. It is almost our "duty" to concrete this in the form of a certification system on the destination level.

- There are very few actors on the market and a thoroughly built system would give the Nordic countries a first-mover advantage.

- It would be advantageous to build upon Destination 21.

$\circ$ E.g. the emphasis put on the organisation of the system and the way in which it helps creating solidarity and ownership.

- Odsherred (one of the two certified destinations) reported in spring 2012 that the certification as such was not nearly as important as the long term effect of the process, which created a fruitful soil for new products and a common understanding of where they are heading.

- The domestic markets in each of the countries are not enough to create the mass. Therefore, it is perceived as the best option to create a Nordic certification system rather than a national one.

- It should not primarily be a "green" certification - the social and economic sustainability should be just as crucial for the destination to be certified.

- There is a need for flexibility in the certification system to reflect the local context.

\section{Members of the group}

- Mikael Backman

- Stefán Gíslason

- Nanna Balsby

- Ulrika Karlsson

- Dan Backman

- Rapporteur: Nanna Balsby 
Figure 3. Groupwork - Group 2: Dan Backman, Ulrika Karlsson, Nanna Balsby and Mikael Backman

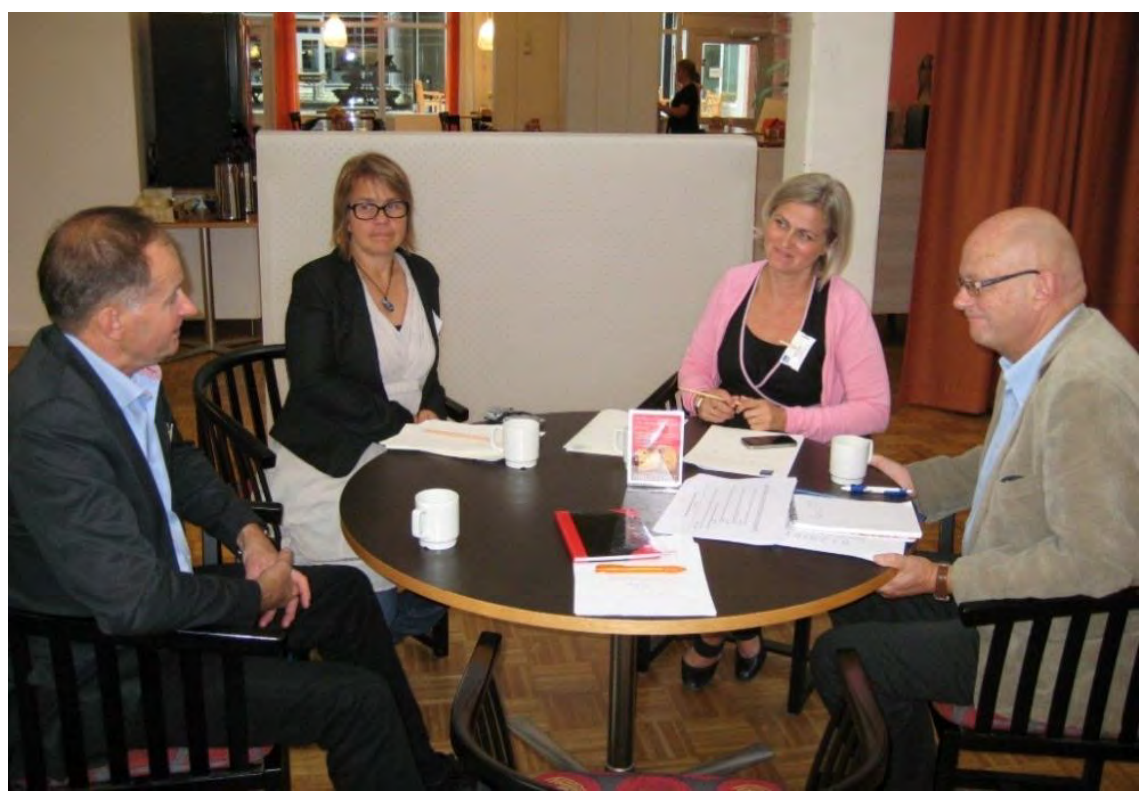

Photo: Stefán Gíslason.

\subsubsection{Group 3}

\section{Four most interesting points of the day}

- The devil is in the details: Make the certification system easy to start with. Otherwise it will end up in a mess!

- Destinations have to ask themselves: Do we have an opportunity to make a difference? Can we use that as a marketing advantage?

- Performance criteria (green mapping - what do we have to start with?).

- Must include progress and on-going learning $\rightarrow$ Innovation!

- Those who gain are:

○ The destination.

○ The tourist.

\section{Answer to the questions}

- The Nordic countries should consider creating their own system for sustainability certification of tourist destinations, BUT with more research before starting up. This would be a Nordic alternative to support the development and to compare destinations. The group wondered about the difference between the countries - even between destinations within each country. Would the same certification apply? Should we develop the system based on some 
groups of standards that apply to different situations? Such a system should have mandatory criteria (process indicators). A Nordic system would be a good marketing opportunity for the Nordic countries, which the visitor often perceives as a whole. It would also mean a lot as a support system, exchange of knowledge, for the people working on certified destinations on a comparable level.

\section{BUT FIRST!}

Each Nordic Country $\rightarrow$ common potential criteria/process + performance $\rightarrow$ map initiatives + good practices $\rightarrow$ see commonalities + differences $\rightarrow$ define next steps!

\section{Members of the group}

- Herbert Hamele.

- Theódóra Matthíasdóttir.

- Christina Rådelius.

- Evelina Persson.

- Rapporteur: Theódóra Matthíasdóttir. 


\section{Recommendations}

\subsection{Main conclusion}

The Nordic countries should develop a common Nordic system for sustainability certification of tourist destinations. The need exists according to the report "Hållbarhetscertifiering av turistdestinationer. Utredning av möjligheter $i$ en nordisk kontext: Befintliga standarder eller ett nytt nordiskt system?" published in the TemaNord series, 2012.2 Existing and upcoming systems do not seem to meet this need. This situation provides an opportunity for the Nordic countries that are known for being "green" and for having a political interest in sustainable development. A properly developed system for sustainability certification of tourist destinations could give them a first-mover advantage.

Building up a system like this demands a proper preparation, based on research and existing experiences. The content of the system has to be properly designed and a special attention has to be paid to the institutional structure and long-term functionality, including financing and capabilities for future development, revising of criteria, etc.

\subsection{Destinations defined}

Involved actors need to have a common understanding of concepts from the beginning. The destination concept is central in this respect. As pointed out in an array of tourist studies there is however still confusion as to what the destination concept actually means, ${ }^{3}$ even though this concept is very much in focus in such studies.

At first glance destination might be defined as a geographical region, i.e. an area with certain spatial boundaries. This is however far from

2 Stefán Gíslason and Venus Krantz (2012): Hållbarhetscertifiering av turistdestinationer. Utredning av möjligheter i en nordisk kontext: Befintliga standarder eller ett nytt nordiskt system? TemaNord 2012:531. Nordic Council of Ministers, Copenhagen. http://www.norden.org/sv/publikationer/publikationer/2012-531 ${ }^{3}$ Anna Dóra Sæpórsdóttir (2011): Wilderness tourism in Iceland - land use and conflicts with power production PhD-thesis, Faculty of Science, University of Oulu, Finland. Nordia Geographical Publications, Volume 40:2. 
being an appropriate definition, because a place first becomes a destination when someone comes for a visit. It is in other words the visitior or the tourist that creates the destination in the first place by perceiving it as such. A bit more appropriate definition would be "a place or a region affected by tourism". ${ }^{4}$ To become a tourist destination, a place has to have a combination of resources, actors and activities that gives the destination a certain identity and maintains it.

According to Jarkko Saarinen "[d]estination is by nature a problematic concept. It refers to a varying range of spatial scales (i.e. levels of representation) in tourism: continents, states, provinces, municipalities and other administrative units, tourist resorts or even single tourist products. Spatial scales and definitions of destinations based on administrative or other such units are sometimes useful and practical, but theoretically they tend to approach tourism as a spatial and geographical phenomenon from a technical and static viewpoint." 5 In fact "the destination can be conceptualized as a historically produced structure which is experienced and represented through different administrative, economic and cultural practices." 6

The UNWTO definition of tourist destination builds a useful base, stating that a "local tourism destination is a physical space in which a visitor spends at least one overnight. It includes tourism products such as support services and attractions, and tourism resources within one day's return travel time. It has physical and administrative boundaries defining its management, and images and perceptions defining its market competitiveness. Local destinations incorporate various stakeholders often including a host community, and can nest and network to form larger destinations." 7 However, this definition is a broad one, as according to it destinations could be "on any scale, from a whole country (e.g. Australia), a region (such as the Spanish "Costas") or island (e.g. Bali), to a village, town or city, or a self-contained centre (e.g. Center Parc or Disneyland)", as explained by UNWTO. ${ }^{8}$ Thus a more detailed definition is needed in order to create an appropriate target for certification.

\footnotetext{
${ }^{4}$ Edward Huijbens and Gunnar Pór Jóhannesson (2013): Ferðamál á Íslandi - fræði, framkvæmd og ferðapjónusta. Forlagið (Mál og Menning), Reykjavík. (To be published).

5 Jarkko Saarinen (2004): "Destinations in change": The transformation process of tourist destinations.

Tourist Studies, 4(2), s. 164.

${ }^{6}$ Ibid, s. 165.

7 World Tourism Organization UNWTO (2007): A Practical Guide to Tourism Destination Management.

[http://pub.unwto.org/WebRoot/Store/Shops/Infoshop/4745/8BCE/AD9A/ECA8/048B/C0A8/0164/0B

7A/071115_practical_guide_destination_management_excerpt.pdf]. 8 Ibid.
} 
The above considerations, the results from the Environice study and several comments from the workshop participants can be summarized into the following five criteria, which would all have to be met in order for a tourist destination to be eligible for sustainability certification as proposed in this paper:

- A geographic place or area with certain physical boundaries where people live in an organized fashion for a long time and which bears visible and permanent traces of social formation in the form of houses and other buildings where people live and spend time.

- A community where people share a common economic, social and industrial infrastructure, common institutions and, to a greater or lesser extent, a common culture.

- A community that is wholly or partially dependent on tourism for its survival.

- An administrative unit with certain administrative boundaries and a properly constituted community authority or a destination management organization (DMO), such as a local government, with its own budget and power to make decisions regarding the management of the destination.

- In most cases a locality, a town, a municipality or a group of municipalities below regional level (sub-regional).

\subsection{Institutional framework}

The Nordic certification system for destinations needs to have a vivid and stable institutional base. A decision on the institutional framework needs to be made during the initial stage of development, preferably within the Nordic Council of Ministers, i.e. by the Nordic Council of Ministers for the Environment (MR-M), on one hand, and the Nordic Council of Ministers for Business, Energy \& Regional Policy (MR-NER) on the other.

The Nordic Swan should be seen as a role model regarding the institutional framework. The system could theoretically be hosted by the Swan. The nature of the two systems is however different, since the Nordic Swan is a type- 1 ecolabel with criteria for products and services, while a certification system for destinations needs to have a wider and somewhat more flexible approach, with criteria for a destination as a whole. If the system is not hosted by the Swan it should be hosted by another relevant Nordic organisation, either an existing or a new one. The Nordic Innovation Centre (NICe) could be a central actor in this respect. 


\subsection{Starting point}

A Nordic system for sustainability certification of tourist destinations should build on the core indicators developed by the EU Commission's TSG (Tourism and Sustainability Group) in 2009, as well as on the GSTC criteria for the destination level, which will be available before the end of 2012. ISEAL's credibility principles should also be taken into account. It should be the goal from the beginning to have the standard recognised and the system approved/accredited by GSTC when the GSTC accreditation system has been developed for the destination level.

At the same time that the Nordic system has to be comparable and be on a high international level of quality and sustainability, it also needs to be on an appropriate level from a Nordic perspective. This means that the system will be somewhat different from a system designed for the $\mathrm{EU}$ as a whole, in being more specific and with stricter requirements on a number of issues. The criteria of the system should be achievable by a maximum of $30 \%$ of Nordic destinations.

European actors have already been operating environmental and sustainability certification systems for different sectors for 25 years. This experience is highly valuable when building up a Nordic system for destinations. EUROPARC, the Austrian Ecolabel and Tourcert are three of further examples of actors with a long experience of well-established systems for certification related to tourism. Many of the criteria of these systems are quite relevant for destinations, such as criteria on local/regional revenues. Ideas and opportunities for partnership could also be found in relation to the Scandinavian Sustainable Meetings Accord. Furthermore, destination management has been on the agenda of EMAS.

More than 20 years of experience and vast knowledge has been collected during the Nordic cooperation around the Swan ecolabel. The Nordic Swan should play an important advisory role during the development phase of a Nordic system for sustainability certification of tourism destinations, even though it may not fit in as a part of the Swan system as such.

It would be advantageous to build upon the experience and knowledge acquired during the development of Destination 21 in Denmark. The emphasis put on the organisation of the system is among the most valuable parts in this respect.

The certification system being developed by Innovation Norway could be used as a basic platform for the Nordic system. It is highly recommended that Innovation Norway is involved in the development of the system from near the beginning. 


\subsection{Funding}

Funding of the new system should be included in any planning of the system from the beginning. It is essential to make it as clear as possible from the start how the system can be maintained over a longer period of time. Government funding will be needed in the development phase and to some extent further on.

The first stages of the process, within the destinations, would require local or regional funding, while the later steps, such as the audit and certification, would need to be financed nationally to a greater extent.

\subsection{Content}

\subsubsection{The system}

A few factors are essential as parts of the system. First of all, the sustainability of the whole destination should be in focus. The system should, in other words, both cover the destination as a geographical area and the operations of the destination management organisation. It is also essential to take all three pillars of sustainable development into account. The system needs, in other words, to focus on social, cultural and economic issues, as well as the environmental ones.

Public participation should be highly prioritised while developing the system, as well as later on, to ensure inclusion and motivation at the destination level. This applies both to the general public, companies, organisations and other stakeholders, both in the tourism sector and other sectors of the economy. Furthermore, processes for innovation, on-going learning, awareness raising, training and knowledge sharing within and between destinations should be a part of the system from the early development on.

The system should be a single state system where destinations either "pass or fail". Recertification should be required at least every third year and the destinations should be required to hand in annual reports with reliable performance data. External auditors should be employed.

Accessibility and transparency should be among the main priorities of the system. Standards, criteria, indicators, guidelines and any other basic documents related to the system should be disclosed at all times.

The system should have a built-in flexibility to reflect the local context, as destinations may vary considerably between the Nordic countries and even within each country, such as because of different popula- 
tion density, location, cultures, etc. Small and remote communities do for instance often face different challenges from a sustainability point of view than more densely populated or more centrally located areas.

Branding and communication, both internally and externally, should be important elements in creating the sense of ownership and authenticity of the system.

\subsubsection{The standard}

The standard needs to include mandatory and optional criteria for processes and performances related to social, cultural and economic aspects, as well as environmental ones, complemented with measurable indicators. The optional criteria are important to recognise and to foster the diversity of destinations. This diversity is quite an important issue from a sustainability point of view and also one of the reasons why a global system is not necessarily a good option.

The criteria should have background in available European and global sources, as described above, complemented by tailor-made indicators applicable to Nordic and local circumstances. Branding should be an obligatory part of the criteria. Furthermore, the criteria should include incentives for the destinations to promote environmental, ethical or sustainability certification of individual companies within the destination.

\subsection{Supporting measures}

The development of a Nordic system for sustainability certification of destinations can be supported in numerous ways through networking and cooperation. When it comes to the point where a handful of destinations have started their preparation for certification or are being certified, a forum for development of Nordic experiences should be established. This would provide the different destinations with opportunities to meet, exchange ideas and experiences, discuss the challenges, identify what has worked out well and what has not etc.

DestiNet could be used to support destinations in the Nordic countries, for instance through own restricted sections creating a platform for the development, operations and monitoring of the certification programme on the local level. This could also be linked to branding and marketing issues. 


\subsection{Important considerations}

A few more issues should be taken into account in the development of a Nordic system for sustainability certification of tourist destinations, in addition to the issues raised above.

It should be underlined that the destination, not the municipality, would be the owner of the certification. The main aim is to involve and develop the tourism sector, not the public authorities. The local government might, on the other hand, often be the destination management organisation. Local authorities would in all cases play a crucial role in the local operation of the system, both from an institutional and financial point of view.

The system has to be made as user-friendly as possible, especially during the initial stages. Any unnecessary bureaucracy would undermine the system and hamper its success.

A certification system as proposed in this report is likely to create a fruitful soil for new products and a common understanding of where the Nordic countries are heading. At the same time it would bring new opportunities for the marketing of the Nordic countries, which the visitor often perceives as a whole.

Even though the certification will always be the central part and the main objective of the system, it should be kept in mind that the long term effect of the certification process as such may actually be the most valuable part of all. 



\section{Sammanfattning}

En expertworkshop om hållbarhetscertifiering av turistdestinationer hölls på Naturvårdsverket i Stockholm tisdagen 11 september 2012. Målet med denna workshop var att skapa en professionell och pålitlig grund för beslutstagning och policybestämmelser inom Nordiska minsterrådet och de individuella nordiska länderna, angående hållbarhetscertifiering av turistdestinationer.

På en global skala är antalet system för hållbarhetscertifiering av turistdestinationer relativt litet. En studie som utfördes 2011 av Environice (Stefán Gíslason och Venus Krantz) för Nordiska ministerrådet identifierade endast fyra system som finns för miljö- och hållbarhetscertifiering av turistdestinationer. En av rekommendationerna från studien var att de nordiska länderna borde utveckla sitt eget system för certifiering för det här.

Workshopen i Stockholm hade som syfte att bygga vidare på Environice-studien och att utforska och vidga dess rekommendationer, genom att ta med fler intressenter med olika synpunkter, samt genom att dela kunskap och erfarenheter från relevanta projekt och pilotfall. Workshopen hölls i uppdrag av Nordiska ministerrådets Småsamfundsgrupp.

Workshopen hölls under en dag. Första halvan ägnades åt att presentera olika projekt och pilotfall. Under den andra halvan diskuterades observationer från presentationerna och rapporten från Environicestudien parallellt i tre grupper. Ett svar söktes på frågan om huruvida de nordiska länderna, på egen hand eller inom Nordiska ministerrådet, borde skapa sitt eget system för hållbarhetscertifiering av turistdestinationer, eller om de borde bidra till ett sådant system som skapats av någon annan, eller om nationella nordiska initiativ borde utvecklas till ett nordiskt system eller om de nordiska länderna borde vänta på en utveckling inom $\mathrm{EU}$ och på internationell nivå.

De 16 som deltog i workshopen valdes utifrån sina professionella erfarenheter och sitt engagemang i hållbar turism på destinationsnivån, eller mer specifikt inom hållbarhetscertifiering av turistdestinationer. Formellt sett så var workshopen öppen för alla som var intresserade och villiga att bidra till diskussionen. Dock var workshopen mestadels menad för experter och ett begränsat antal deltagare. 
En av de viktigaste slutsatserna från workshopen var att de nordiska länderna borde utveckla ett gemensamt system för certifiering av turistdestinationer. Enligt Environice-rapporten finns behovet och nuvarande och kommande system verkar inte uppfylla detta. Situationen erbjuder en möjlighet för de nordiska länderna, som är kända för att vara "gröna" och för att ha ett politiskt intresse i en hållbar utveckling. Ett system för hållbarhetscertifiering av turistdestinationer som har utvecklats på rätt sätt skulle kunna ge dem ett försprång som de första som agerade.

De inblandade måste ha en gemensam förståelse för konceptet destination. Som tidigare har påpekats i ett flertal turiststudier så råder fortfarande en förvirring angående vad konceptet destination egentligen innebär, till och med då detta koncept står i fokus för dessa studier. Befintliga studier, resultaten från Environice-studien och flertalet kommentarer från workshopen kan sammanfattas till de följande fem kriterierna som alla skulle behöva uppfyllas för att en turistdestination skall vara berättigad till hållbarhetscertifiering, enligt förslaget i det här dokumentet:

- En geografisk plats eller ett område med bestämda fysiska gränser, där människor lever under organiserade former under en längre tid och vilket bär synliga och permanenta spår av samhällsbildningen i form av hus och andra byggnader, där människor lever och vistas.

- Ett samhälle där människor delar en gemensam ekonomisk, social och industriell infrastruktur, gemensamma institutioner samt, i högre eller lägre grad, en gemensam kultur.

- Ett samhälle som helt eller delvis är beroende av turism för sin överlevnad.

- En administrativ enhet med bestämda administrativa gränser och en myndighet som inställts på rätt sätt, eller en "destination management organisation" (DMO), såsom en lokal myndighet med sin egen budget och makt att ta beslut gällande skötseln av destinationen.

- I de flesta fall innebär detta en lokalitet, en tätort, en kommun eller en grupp av kommuner som befinner sig under regionalnivå (subregional).

Det nordiska certifieringssystemet för destinationer behöver ha en levande och stabil institutionell bas. Ett beslut behöver tas angående det institutionella ramverket redan under utvecklingens tidiga stadie, helst inom Nordiska ministerrådet, det vill säga inom Nordiska ministerrådet för miljöfrågor (MR-M) å ena sidan, och Nordiska ministerrådet för näringsliv, energi och regionalpolitik (MR-NER) å andra sidan. Den nordiska Svanen bör ses som en förebild vad gäller ramverk. 
Ett nordiskt system för hållbarhetscertifiering av turistdestinationer bör bygga vidare på de kärnindikatorer som utvecklats av EU-kommissionens grupp för turism och hållbarhet (TSG) 2009, såväl som GSTC-kriterierna för destinationer, vilka kommer att göras tillgängliga innan 2012 är slut. ISEAL:s principer för trovärdighet bör även has i åtanke.

Samtidigt som det nordiska systemet måste vara jämförbart och ligga på en hög internationell nivå kvalitetsmässigt och i fråga om hållbarhet, bör det befinna sig på en lämplig nivå utifrån ett nordiskt perspektiv. Detta innebär att systemet kommer att skilja sig från ett eventuellt system för hela EU genom att vara mer specifikt och ha striktare krav på en rad punkter. Systemets kriterier skall kunna uppnås utav högst $30 \%$ av nordiska destinationer.

Mer än 20 års erfarenhet samt bred kunskap har samlats under det nordiska samarbetet runt det nordiska miljömärket Svanen. Svanen bör spela en viktig rådgivande roll under utvecklingsfasen av ett nordiskt system för hållbarhetscertifiering av turistdestinationer, trots att detta kanske inte passar in som del i Svanen-systemet i sig. Det vore också förmånsfullt att bygga vidare på erfarenheten från utvecklingen av Destination 21 i Danmark.

Certifieringssystemet som utvecklas av Innovasjon Norge skulle kunna användas som basplattform för det nordiska systemet. Det rekommenderas verkligen att Innovasjon Norge finns med i bilden från systemutvecklingens början.

Finansiering för det nya systemet måste finnas med i planering av systemet redan från början. Det är viktigt att det klargörs från första början hur systemet kan bevaras under en längre tid. Statlig finansiering kommer att behövas under utvecklingsstadierna och till viss del framöver.

En del faktorer är väsentliga delar i systemet. Först och främst så ska hållbarheten för hela destinationen ligga i fokus. Det är även viktigt att beakta alla tre stolpar för hållbar utveckling. Systemet behöver, med andra ord, vara fokuserat på sociala, kulturella och ekonomiska frågor, såväl som miljöfrågor.

Allmänhetens inblandning bör prioriteras högt och processer för innovation, pågående utbildning, ökning av medvetande, samt träning och kunskapsutbyte inom och emellan destinationerna bör utgöra en del av den tidiga utvecklingen.

Systemet borde ha en enhetlig nivå och utvärdera destinationer som "God-kända" eller "Icke godkända". Omcertifiering skall krävas minst en gång var tredje år och destinationerna bör vara tvungna att lämna in årliga rapporter med tillförlitlig information om prestanda. Utomstående revisorer borde anställas. 
Systemet borde ha en inbyggd flexibilitet som återger den lokala kontexten, då destinationer kan variera avsevärt mellan de nordiska länderna och även inom ett samma och land. Detta är resultatet av variationer i tätbebyggelse, lokalitet, kulturer, o.s.v. Små och avlägsna samhällen möter till exempel annorlunda utmaningar utifrån en hållbarhetssynpunkt än de mer tätbebodda och mer centrala områdena. Standarden bör inkludera obligatoriska och valfria kriterier för processer och prestanda, vilka sedan komplementeras med mätbara indikatorer.

Systemet måste göras så användarvänligt som möjligt, speciellt under de tidiga stadierna. Onödig byråkrati i någon form skulle undergräva systemet och hämma dess framgång.

Det är troligt att ett certifieringssystem som det som föreslås i den här rapporten skulle skapa en fruktsam grund för nya produkter och ett allmänt förstående av vart de nordiska länderna är på väg. Samtidigt skulle det ge nya möjligheter för marknadsföring av de nordiska länderna, vilka besökare ofta upplever som en helhet.

Trots att certifieringen alltid kommer att ha en central roll och vara det huvudsakliga målet med systemet skall det kommas ihåg att långtidseffekterna av certifieringsprocessen i sig kan komma att bli den mest värdefulla delen av alltihop. 


\section{Appendix 1: Workshop program}

\section{norden}

PROGRAM

\section{Workshop program}

Tuesday 11 September 2012

Time 10:00 - 16:00 Stockholm (Sweden)

\section{0:00 to $10: 15$ \\ Registration and coffee}

$10: 15$ to $10: 30$

Welcome and today's program

[Maria Gunnleivsdóttir Hansen,

Chairman of The Nordic Group for Small Communites]

$10: 30$ to $10: 50$

Highlights from the Environice-report

[Venus Krantz and Stefán Gislason, authors of the report]

$10: 50$ to $11: 20$

Sustainable tourist destinations - Trends and future prospects [Herbert Hamele, Founder and chairman of the European network for sustainable tourism development ECOTRANS]

\section{1:20 to 11:30 Break}

11:30 to 11:50 Sustainable tourist destinations - Some reflections from practice [Mikael Backman, IIIEE, Lund University]

11:50 to 12:10 EarthCheck certification of Snæfellsnes, Iceland - The experience [Theódóra Matthíasdóttir, Environmental coordinator, Snæfellsnes region]

12:10 to $13: 00$ Lunch

13:00 to $13: 20$

Sustainable tourism 2015 - A Norwegian system for sustainability certification of tourist destinations

[Ingunn Sørnæs, Project leader, Innovation Norway]

$13: 20$ to $13: 40$

The Swedish way towards sustainable tourism destinations - An integrated quality and sustainability approach supporting every business [Christina Rådelius, Program director, Swedish Agency for Economic and Regional Growth - Tillväxtverket]

13:40 to 14:00 Sustainability certification of tourist destinations - Can this be linked to The Nordic Swan?

[Björn-Erik Lönn, Co-ordinator for the Nordic Ecolabel]

14:00 to $14: 10$

Break

$14: 10$ to $14: 40$

\section{Group work - First half}

The presentations and the report from the Environice-study will be discussed in 4 groups. At the end of the first half the members of each group should have agreed upon and listed the 4 most important and/or interesting points from the study and/or the presentations - in order of priority. The results should be documented in the form of a short note.

$14: 40$ to $15: 20$ Group work - Second half

Based on the presentations and the report from the Environice-study each group should agree upon an answer to this question:

- Should The Nordic countries, each of them or within the Nordic Council of Ministers, create their own system for sustainability certification of tourist destinations,

- should they contribute to such a system created by someone else,

- should national Nordic initiatives be developed into a Nordic system or

- should the Nordic countries await the development within EU and on the international level?

The results should be documented in the form of a short note.

15:20 to $15: 35$ Coffee break

$15: 35$ to $15: 55$ Presentation of group work results [One member of each group] 



\section{Appendix 2: Workshop participants}

\begin{tabular}{llll}
\hline No & Name & Institution & Country \\
\hline 1 & Björn-Erik Lönn & Nordic Ecolabelling & Nordic \\
2 & Christina Rådelius & Tillväxtverket & Sweden \\
3 & Dan Backman & Åland Government & Åland \\
4 & Desiré Haglund & Trossa & Sweden \\
5 & Evelina Persson & Lund University & Sweden \\
6 & Herbert Hamele & ECOTRANS & Germany \\
7 & Ingunn Sørnes & Innovation Norway & Norway \\
8 & Louise Rabilloud & Green Key & Sweden \\
9 & Maria Gunnleivsdóttir Hansen & EPA Faroe Islands & Faroe Islands \\
10 & Mikael Backman & Lund University & Sweden \\
11 & Nanna Balsby & NB Tourism & Denmark \\
12 & Stefán Gíslason & Environice & Iceland \\
13 & Theódóra Matthíasdóttir & Snæfellsnes region & Iceland \\
14 & Ulf Eklund & Åland tourism & Åland \\
15 & Ulrika Karlsson & Swedish EPA & Sweden \\
16 & Venus Krantz & Environice/Lund University & Sweden \\
\hline
\end{tabular}




\section{Sustainability certification of Nordic tourist destinations}

An expert workshop on sustainability certification of tourist destinations was held at the Swedish EPA (Naturvårdsverket) in Stockholm Tuesday the 11th of September 2012. The workshop in Stockholm built on a study, conducted in 2011 by Environice for the Nordic Council of Ministers. The aim was to explore and widen the recommendations from the earlier study with the target to create a professional and reliable foundation for further decision and policy making. The workshop was commissioned by the Nordic Council of Ministers' group on small communities (Småsamfundsgruppen). This report includes a summary of the workshop's group discussions, followed by revised recommendations for future work, based on the workshop results. The main conclusion of the workshop was that the Nordic countries should develop a common Nordic system for sustainability certification of tourist destinations.

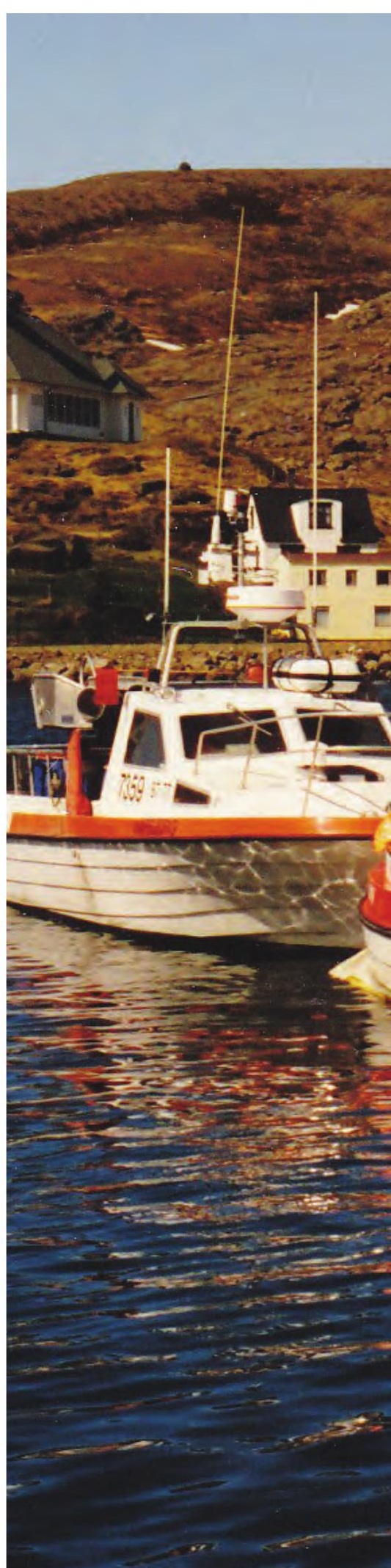

